\title{
Identifying interior design strategies for healthy workplaces - a literature review
}

Susanne Colenberg

Department of Human-Centered Design, Faculty of Industrial Design Engineering, Delft University of Technology, Delft, The Netherlands, and

Tuuli Jylhä

Department of Management in the Built Environment, Faculty of Architecture and the Built Environment, Delft University of Technology, Delft, The Netherlands
Interior design strategies

Received 29 December 2020 Revised 24 June 2021 15 September 2021 Accepted 13 October 2021

\begin{abstract}
Purpose - It is widely recognized that interior office space can affect health in several ways. Strategic and evidence-based design, including explicit design objectives, well-chosen design solutions and evaluation of results, aid realization of desired health effects. Therefore, this paper aims to identify possibly effective interior design strategies and accompanying design solutions and to provide examples of effectiveness measures.

Design/methodology/approach - A literature sample of 59 peer-reviewed papers published across disciplines was used to collect examples of workplace design features that have positively influenced workers' well-being. The papers were grouped by their health objective and design scope successively and their theoretical assumptions, measures and findings were analyzed.

Findings - Four main workplace design strategies were identified. Design for comfort aims at reducing or preventing health complaints, discomfort and stress, following a pathogenic approach. It has the longest tradition and is the most frequently addressed in the included papers. The other three take a salutogenic approach, promoting health by increasing resources for coping with demands through positive design. Design for restoration supports physical and mental recovery through connections with nature. Design for social well-being facilitates social cohesion and feelings of belonging. Design for healthy behavior aims at nudging physical activity in the workplace.

Originality/value - By drawing complementary perspectives and offering examples of design solutions and effectiveness measures, this paper encourages workplace designers, managers and researchers to take a transdisciplinary and evidence-based approach to healthy workplaces. It also serves as a starting point for future empirical research.
\end{abstract}

Keywords Well-being, Employee health, Office, Interior design, Strategic design,

Salutogenic approach

Paper type Literature review

(C) Susanne Colenberg and Tuuli Jylhä. Published by Emerald Publishing Limited. This article is published under the Creative Commons Attribution (CC BY 4.0) licence. Anyone may reproduce, distribute, translate and create derivative works of this article (for both commercial and non-commercial purposes), subject to full attribution to the original publication and authors. The full terms of this licence may be seen at http://creativecommons.org/licences/by/ 4.0/legalcode

This study re-used data which were collected by Colenberg $\mathrm{et}$ al. (2020) to provide an overview of the evidence on the relationship between interior office space and health. Previous analysis and a shorter version of this paper were published in the proceedings of the 2020 Transdisciplinary Workplace Research Conference.

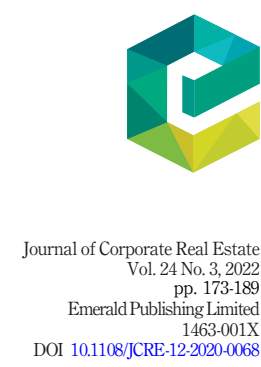


JCRE 24,3

\section{Introduction}

A growing body of research is suggesting that workplace design is essential to the successful execution of business strategy (Chan et al., 2007) and to organizational performance (Van de Voorde et al., 2012). The awareness of the possible health impact of building interiors has grown in recent years (Hanc et al., 2019; Jensen and Van der Voordt, 2020; World Green Building Council, 2014) and has become even more urgent during the COVID-19 pandemic (Cirrincione et al., 2020). Yet, a workplace is a complex composition of many different and sometimes conflicting elements. For example, measures to prevent virus spread could be at odds with acoustical comfort due to easy-to-clean yet sound-reflecting surfaces or they could interfere with relatedness due to physical distancing that separates colleagues.

Creating healthy work environments, therefore, requires a wide view of potential health hazards and invigorators. Nevertheless, researchers and practitioners can have a blind spot for workplace factors that are not in the usual scope of their own discipline. For instance, in the field of organizational behavior the influence of the physical work environment has long been ignored (Ayoko and Ashkanasy, 2020) and in facilities and real estate management the research on health and well-being is fairly limited (Jensen and Van der Voordt, 2020). Therefore, the aim of this paper is to draw different perspectives on healthy workplaces and provide leads for strategic and evidence-based workplace design and transdisciplinary workplace research.

\section{Workplace and health}

Workplace can refer to the physical or the psychosocial work environment from the perspective of the organization or the individual user, differing from one sector to another. This study focuses on the physical work environment from the perspective of interior design. Interior design directly connects humans and space. It includes form, finish and spatial arrangement of design features such as spatial partitions and transitions, furnishings, lighting fixtures and sources, sound isolation, finish materials, accessories and technologies relating to space (Ching and Binggeli, 2018). It reaches beyond decoration and includes spatial (architectural) elements, but it excludes building construction and engineering. The interior design usually is changed more easily and more frequently than the structural design or air-conditioning layout. Second, as well-being can be considered a primarily individual benefit of healthy workplaces (Jensen and Van der Voordt, 2020), this study refers to the workplace as perceived by the individual user. Finally, this study focuses on office workplaces because office workers are the largest occupational group (U.S. Bureau of Labor Statistics, 2020) and offices are relatively comparable workplaces.

Regarding healthy workplaces, traditionally the emphasis has been on physical health, for instance as a consequence of air quality in office buildings. Polluted air has been identified as a health hazard since the times of the Greek and Roman empires. The sick building syndrome that emerged in the 1980's associated physical complaints of office workers with, for instance, mold and toxic emissions of building materials and machines. However, already in 1948, the World Health Organization defined health as "a complete state of physical, psychological and social well-being" (WHO, 2006), uniting medicine and social science and equating health to well-being. More recently, an even wider perspective is advocated, including the dynamic ability to adapt and to manage one's own well-being (Huber et al., 2011). Designing a healthy workplace can, thus, have different starting points depending on the health perspective. This study takes on the widely accepted WHO definition of health. 
Strategic workplace design aligns the design of the work environment with the long-term goals of the organization and might even be used to meet new challenges or create new possibilities (Chan et al., 2007). For example, if a company wants to increase productivity or innovation, it may decide that to achieve this goal the work environment should support employee health as much as possible, believing that healthy workers are more productive and creative. This strategy may include specific health objectives and the use of design solutions that have shown to improve these health aspects directly or by stimulating healthy behavior.

As health has many faces, ideally, the responsible departments of the organization work together to envision and create an optimal workplace. Then they would brief the workplace designer with desired health effects of the new work environment and evaluate results to keep improving and responding to organizational changes, while the designer makes design decisions based on the best available evidence. In addition, researchers from different disciplines ideally work together to increase understanding of the relationship between workplace design and health. However, this is not common practice yet. Apart from segregation between disciplines, another complicating factor is that current research on wellbeing in office buildings often lacks clarity of design objectives and well-being conceptualizations (Engelen et al., 2019; Forooraghi et al., 2020; Hanc et al., 2019).

More explicit design strategies including well-chosen design solutions can direct workplace design and research toward desired health effects and support organizational goals. Furthermore, examples of scientific outcome measures show how to systematically test assumptions regarding the effects of the applied design, thereby building up evidence to inform future design. Therefore, this study aims to contribute to a transdisciplinary and evidence-based approach to workplace design and design research by answering the following research questions:

$R Q 1$. Which interior design strategies including evidence-based design solutions can be identified based upon scientific research on the relationship between workplace design and health?

$R Q 2$. How can the effectiveness of these interior design strategies be measured?

\section{Method}

An existing database from a literature review that synthesized results on the impact of interior office space on employee health (Colenberg et al., 2021) was used to identify the interior strategies. The database offered a way to include a broad sample of empirical workplace research and evidence-based workplace research for a semi-systematic literature review. According to Snyder (2019), semi-systematic literature reviews synthesize topics that are studied by various groups of researchers and contribute to understanding relevant research traditions.

The database was created by a systematic and transparent search procedure, which included entering every combination of six design-related and six health-related search terms (Table 1) into Scopus and Web of Science.

By using general terms for office space and occupational health rather than specific design elements or health complaints, finding studies from different disciplines was supported. The database contained 2,816 papers that were published in peer-reviewed journals between 1995 and 2018 .

From the existing database, we extracted 59 papers using the following inclusion criteria:

- studying interior design (as defined by Ching and Binggeli, 2018) of an office environment;

- measuring health (as defined by the WHO, 2006) or healthy behavior; 
JCRE 24,3

Table 1.

Search terms that were used in 6 (interior) $\times 6$ (health) combinations to create the database

- reporting a clear and systematic research method; and

- written in English.

Based on these criteria, we excluded papers on employee health that did not relate indoor conditions to interior design features. After subsequently screening title, abstract and fulltext, we included 59 research and review papers for analysis.

From each paper in the sample, we extracted data on approach and outcomes (Figure 1) using a template created for this purpose. Next, we applied qualitative content analysis using descriptive and concept coding (Miles et al., 2020). We first grouped papers with a similar health aim and subsequently grouped them by design scope. Studying theoretical assumptions and rationales per health group revealed implicit design goals. Based on the reported findings per design subgroup, we identified which design solutions could help to achieve which goal. By combining these possible goals and solutions that emerged from the papers we distinguished different design strategies. Outcome measures that were applied in each group served as examples of how to determine the strategy's effectiveness. We divided them into self-report measures of perceived well-being and objective measures of actual health and behavior.

Interior office space

Physical work environment*

Office environment*

Office setting*

Workplace design*

Office design*

Office building*
Office workers' health

Health

Well-being

Well-being

Musculoskeletal

Burnout

Stress

Note: The * was used to include singular and plural forms in one search string

Figure 1.

Approach of literature review to identify interior design strategies for healthy office workplaces and measures of effectiveness

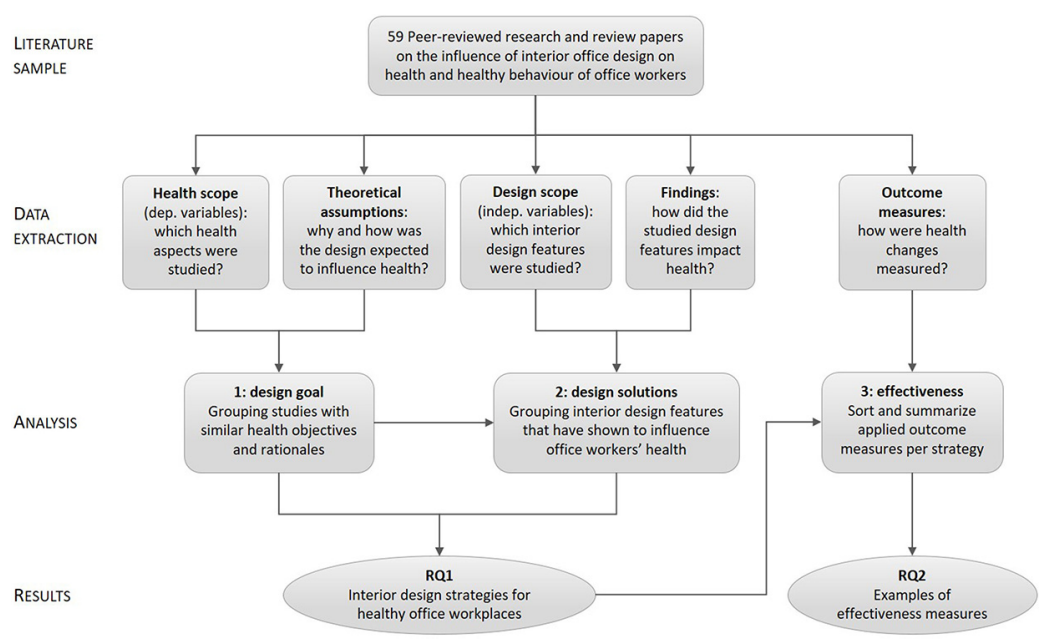




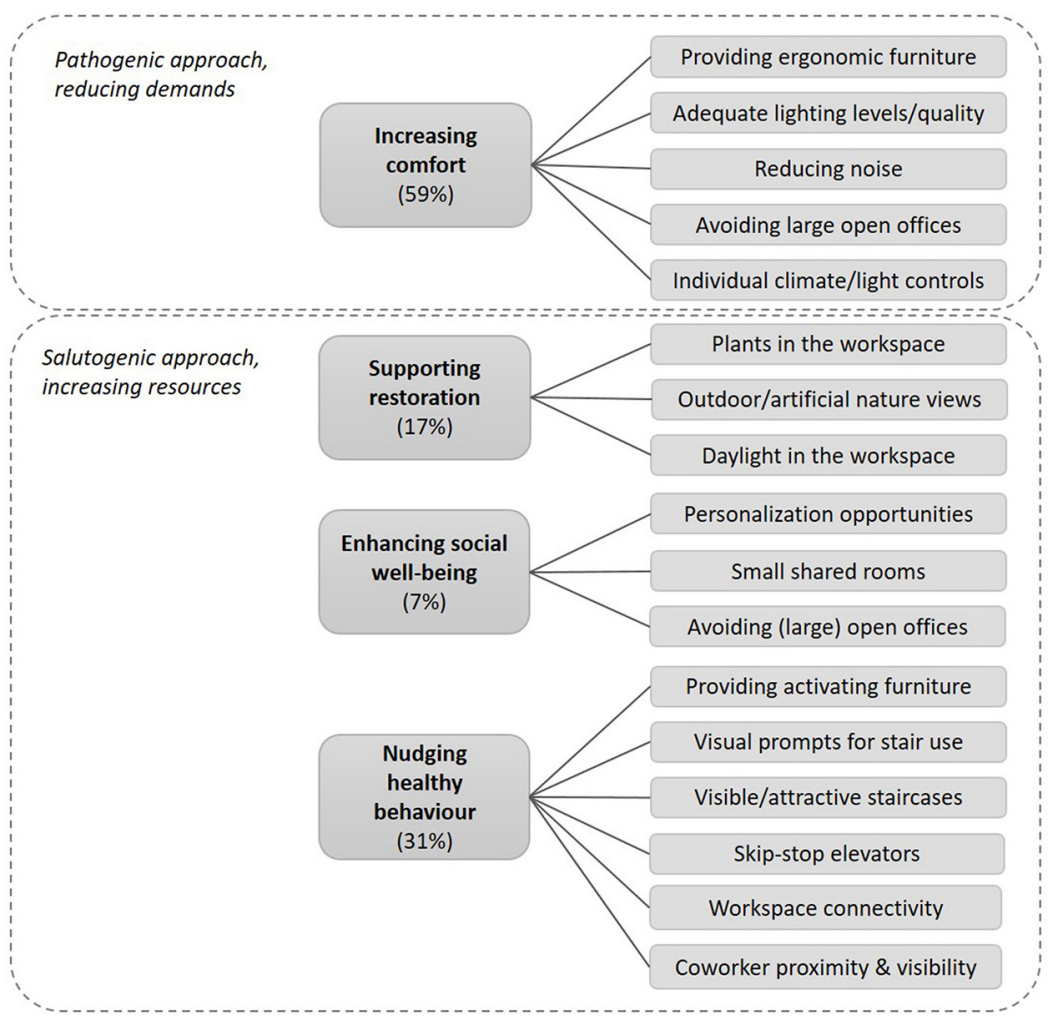

Interior design
strategies

177

Figure 2.

Identified design strategies (\% of the included papers) for healthy office workplaces including examples of evidencebased interior design solutions

\section{Results}

We identified four design strategies for healthy office workplaces, aiming at office workers' comfort, restoration and social well-being and stimulating healthy behavior (Figure 2).

The presented design strategies are not mutually exclusive; some papers included elements of different strategies. The most dominant strategy in the considered time-span (59\% of the included papers, Figure 2) focuses on reducing environmental demands and decreasing harm and health risk, which refers to a pathogenic approach. The other three take a salutogenic approach (Antonovsky, 1996), aiming for renewal and increase of resources for coping with demands in the workplace. They relate to positive design that is explicitly intended to support human flourishing by, for instance, generating pleasure, personal significance and virtue (Desmet and Pohlmeyer, 2013).

\section{Design for comfort}

The most prominent strategy emerging from the selected papers aims to create a comfortable environment that protects users from physical and mental harm and stress. It has the longest tradition and can be considered the foundation of healthy workplaces, rooted in disciplines such as occupational health and safety, health psychology, ergonomics, building technology and medical science. The majority of the selected papers in this review were predominantly directed toward the office worker's physical or psychological comfort. They frame the research within knowledge on medical conditions such as cardiovascular 
JCRE 24,3

diseases and musculoskeletal issues or take the psychological stress perspective: support of employee functioning (Vischer, 2008), the balance between environmental resources and demands (Demerouti et al., 2001) and privacy theory (Altman, 1975).

Ten papers investigated the health risks of different office types, comparing physical health conditions, environmental stress, mood or sickness absence between occupants of workspaces varying in architectural openness and number of workstations (Bodin Danielsson et al, 2014, 2015; Jaakkola and Heinonen, 1995; Lindberg et al., 2018; Pejtersen et al., 2006, 2011) or before and after implementation of a different office concept (Brennan et al, 2002; Foley et al, 2016; Haapakangas et al., 2018; Meijer et al., 2009). These studies showed that workspaces for a larger number of people were related to increased health complaints and distractions, especially in open-plan offices without the backup spaces provided by an activity-based working concept. Seven studies aimed at reduction of musculoskeletal discomfort by providing ergonomic furniture designed to fit the user's body (Amick et al, 2012; Van Niekerk et al, 2012; Robertson et al., 2009) or stimulate alternating working positions (Grooten et al, 2017; Karakolis and Callaghan, 2014; Robertson et al., 2013; Roossien et al, 2017). Adjustable chairs were found to reduce discomfort, although it was not clear how much of this could be attributed to accompanying training. A smart chair and sit-stand desks showed mixed results regarding physical comfort.

Eight studies aimed at increasing visual or eye comfort, reducing physiological stress or headaches or improving mood and alertness by more light on the work surface (Van Duijnhoven et al., 2018; Lamb and Kwok, 2016; Thayer et al., 2010), applying different lighting concepts or systems (Fostervold and Nersveen, 2008; Joines et al., 2015; De Kort and Smolders, 2010; Viola et al., 2008) or increasing perceived lighting quality (Veitch et al., 2008). Their findings indicate that adequate light levels and quality improve physical wellbeing and mood, but do not affect alertness.

A well-known source of discomfort and stress in offices is noise. A high level of background noise was found to increase physiological stress, yawning and psychological discomfort (Jahncke et al., 2011; Lamb and Kwok, 2016; Schlittmeier and Liebl, 2015; Shafiee Motlagh et al, 2018; Thayer et al, 2010). Better sound absorption was related to a lower level of perceived disturbances and cognitive stress (Seddigh et al., 2015).

Increasing comfort by offering possibilities to control indoor climate, for example, by being able to open a window, temperature or lighting in the workspace, had mixed results. Self-control was preferred by office workers although actual effects on musculoskeletal, visual or overall comfort or on headaches varied (Bluyssen et al, 2011; Boerstra et al, 2015; Knight and Haslam, 2010; Toftum, 2010). None of the included papers connected interior design to indoor air quality and health, although it was argued that building materials and plants could influence air quality (Fjeld, 2000).

\section{Design for restoration}

A second design strategy for healthy workplaces aims at providing a restorative work environment that supports recovery from physical and mental strain, grounded in environmental psychology and human biology. This strategy takes a step forward from minimizing stressors and misfits. It aims at supporting recovery by implementing principles of biophilic design (Kellert, 2008) to create beneficial connections with nature. Papers in this category refer to attention restoration theory (Kaplan, 1995), stress recovery theory (Ulrich et al., 1991) and the biophilia hypothesis of Wilson (1984).

Seven studies relating to this strategy assessed the influence on fatigue and physiological stress of plants in the workspace (Bjørnstad et al., 2016; Evensen et al., 2015; Fjeld, 2000; Qin et al., 2014) and of real or artificial outdoor nature views 
(Bjørnstad et al., 2016; Kahn et al., 2008; Kweon et al., 2008; Xue et al., 2016). Most of these studies were lab experiments. The results varied from positive health effects to no effect at all, but at least the participants enjoyed the greenery. Other studies, including cross-sectional research designs and field experiments, focused on improving vitality, alertness and sleep quality through increased daylight in the workspace (Bjørnstad et al., 2016; Boubekri et al., 2014) or mimicry of daylight (De Kort and Smolders, 2010; Viola et al., 2008), also with either little or positive results for well-being.

\section{Design for social well-being}

A less explicit design strategy emerging from the selected papers aims at supporting social relationships at work and expression of identity and is grounded in social, organizational and environmental psychology. This strategy differs from the other three by focusing on the outer-directed dimension of well-being that depends on interactions with other people (Fisher, 2014). Studies within this strategy refer to theory on personalization of space (Sommer, 1974), territoriality (Brown et al., 2005) and regulation of social interactions (Altman, 1975) and to the Job Demands-Resources Theory (Demerouti et al., 2001) in which social support serves as a buffer against burnout.

Morrison and Macky (2017) investigated a wide array of social demands and resources in the office and found that small shared rooms are best for friendships at work and that large open-plan offices undermine cooperative behavior and trust and increase negative interpersonal relationships. Wells (2000) studied workspace personalization as a means of increasing well-being. She found that allowance for personalization and the actual display of objects indeed were related to better well-being, mediated by satisfaction with the physical work environment and job satisfaction. Others addressed conflicts or satisfaction with team relations in studies on the effects of office type (Bodin Danielsson et al., 2015; Brennan et al., 2002) or furniture use (Torbeyns et al., 2016), finding that open-plan offices were negatively associated with quality of relationships at work.

\section{Design for healthy behavior}

The fourth, relatively young strategy emerging from the selected papers aims to stimulate health-supporting behavior, namely, physical activity at work. These studies are framed by medical risks of prolonged sitting and theory on behavioral motivation and habits (Aarts and Dijksterhuis, 2000) and implicitly lean on the concept of nudging (Thaler and Sunstein, 2008) comes from behavioral economics and consumer psychology. Currently, nudging is often promoted as a seemingly easy and possibly effective means to influence human behavior and there are several ways to apply it in the physical work environment (Venema and van Gestel, 2021).

The studies within this design strategy all targeted the employees' sedentary behavior or amount of walking in the office. Among furniture offered to decrease sitting time (Barbieri et al., 2017; Carr et al., 2016; Graves et al., 2015; Healy et al., 2013; Torbeyns et al., 2016), sitstand desks generally reduced sitting and increased standing time (while they were less effective in reducing discomfort, as explained before). Having more sedentary breaks was related to greater local connectivity (available routes) and co-worker proximity and visibility (Duncan et al., 2015; Wilkerson et al., 2018). After relocating to an activity-based work environment office workers sat less than before (Foley et al., 2016). An attractive and accessible staircase, as well as breakout spaces and centralized facilities, did reduce sitting time but did not increase moderate or vigorous activity (Jancey et al., 2016). Larger distances
Interior design
strategies 
JCRE 24,3

to the bathroom and kitchen were supposed to increase walking, but this was not confirmed after relocating to the new office buildings (Engelen et al., 2016, 2017).

Other studies focused on increased physical activity by nudging stair use. Signs outside the staircase and an interactive artwork featuring inside doubled the stair use compared to a control group and this effect lasted for at least six weeks (Swenson and Siegel, 2013). However, posters, floor stickers and stair banners had mixed effects. Point-of-choice prompts did work, motivational posters inside elevators did not (Lewis and Eves, 2012). Or posters did increase stair use but after removal, this dropped back to baseline (Kwak et al., 2007). In one case the nudging even lead to reduced stair use because it annoyed the office occupants (Åvitsland et al., 2017). A review by Nocon et al. (2010) also reported contradictory or non-significant results. This shows that prompts might be an effective design solution only in the right form and place and when the nudging is accepted by the target group. Another design solution implemented to increase stair use was making stairs visible and implementing a skip-stop elevator that stops only at every third floor (Nicoll and Zimring, 2009). In other office buildings, open central staircases did not lead to more walking (Engelen et al., 2016, 2017).

\section{Measures for effectiveness}

The outcome measures that were applied in the research papers (Figure 3) serve as examples of how to estimate the effectiveness of a design strategy in achieving health improvement or consolidation.

\begin{tabular}{|c|c|c|c|c|}
\hline Comfort & \multicolumn{2}{|l|}{ Restoration } & Social well-being & Healthy behaviour \\
\hline $\begin{array}{l}\text { Self-report measures } \\
\text { - Perceived comfort (general/ } \\
\text { thermal) } \\
\text { - Musculoskeletal discomfort } \\
\text { - Eyestrain/ visual discomfort } \\
\text { - Perceived lighting quality } \\
\text { - Noise annoyance } \\
\text { - Disturbance } \\
\text { - Satisfaction with privacy } \\
\text { - Perception of cramped space } \\
\text { - Unpleasant odour } \\
\text { - Percieved air quality } \\
\text { Objective measures } \\
\text { - Observed sitting postures, } \\
\text { - upper body movements } \\
\text { - Bighting level (lux) } \\
\text { - Sackground sound level (dBA) } \\
\text { - Radius of acoustic comfort }\end{array}$ & \multicolumn{2}{|c|}{$\begin{array}{l}\text { Self-report measures } \\
\text { - Alertness, sleepiness, } \\
\text { fatigue, feeling 'off' } \\
\text { - Mood, irritability, anger } \\
\text { - Need for recovery } \\
\text { - Experienced restoration } \\
\text { - Vitality / energy } \\
\text { - Perceived sleep quality } \\
\text { - Reported physical or } \\
\text { - } \text { social function } \\
\text { - Perceived fascination }\end{array}$} & $\begin{array}{l}\text { Self-report measures } \\
\text { - Satisfaction with team } \\
\text { member relations } \\
\text { - Co-worker friendships } \\
\text { - Supervisor support } \\
\text { - Organizational } \\
\text { support } \\
\text { - Frequency of conflicts, } \\
\text { distractions } \\
\text { - Negative relationships } \\
\text { - Cooperative } \\
\text { atmosphere, trust } \\
\text { - Possibilities for } \\
\text { personalization } \\
\text { Objective measures } \\
\text { - Manually observed } \\
\text { workspace } \\
\text { personalization }\end{array}$ & $\begin{array}{l}\text { Self-report measures } \\
\text { - Reported sitting/ } \\
\text { standing/ walking } \\
\text { time at work } \\
\text { - Frequency of breaks in } \\
\text { sitting time } \\
\text { - Reported stair/ lift use } \\
\text { - Level of physical } \\
\text { activity } \\
\text { Objective measures } \\
\text { - Step count } \\
\text { - Observed } \\
\text { sitting/standing time, } \\
\text { - } \text { sit-stand transitions } \\
\text { Observed stair/ lift use }\end{array}$ \\
\hline \multicolumn{5}{|c|}{ General health/well-being of office workers } \\
\hline \multicolumn{2}{|c|}{$\begin{array}{l}\text { Self-report measures (surveys) } \\
\text { - General physical/ mental health (rating), health concerns } \\
\text { - Mood, anxiety, depression, tiredness, feelings of stress } \\
\text { (physical/ cognitive) } \\
\text { - Sick building symptoms: headache, eye/ ear/ nose/ throat/ } \\
\text { skin irritation, nausea, feeling heavy headed, fatigue } \\
\text { - Musculoskeletal complaints (e.g. lower-back pain) } \\
\text { - Visual symptoms (e.g. blurred vision, difficulty focusing) } \\
\text { - Reported sickness absence, number of common colds } \\
\text { - Reported use of pain killers or sleep medication }\end{array}$} & \multicolumn{3}{|c|}{$\begin{array}{l}\text { Objective measures (e.g. by medical equipment) } \\
\text { - Physiological stress: saliva cortisol, skin conductance, heart } \\
\text { rate variability, EEG, ECG, respiration rate, fingertip blood } \\
\text { flow, oxyhaemoglobin saturation, urine catecholamines } \\
\text { - Cardio-metabolic biomarkers: systolic blood pressure, } \\
\text { cholesterol, triglycerides, blood glucose level } \\
\text { - Anthropometrics: waist cricumference, body mass index, } \\
\text { fat percentage, spinal shrinkage } \\
\text { - Aerobic fitness: peak } \mathrm{VO}_{2} \text {, resting heart rate } \\
\text { - Tracked sleeping time and fragmentation } \\
\text { - Registered/certified sick leave days }\end{array}$} \\
\hline
\end{tabular}

Figure 3.

Effectiveness measures regarding health outcomes as applied in the included research papers 
As well-being primarily is a subjective experience, many of the studies applied self-report measures, either by using previously validated scales, such as the perceived stress scale (Cohen et al., 1983) and the perceived restorativeness scale (Hartig et al., 1997) or -more often - newly created questionnaires. They address, for example, health complaints, sickness leave, environmental stress, interpersonal relationships and estimated physical activity and usually are created for one study only with limited testing of validity and reliability.

Objective health measures included examination of bodily fluids, heart rate recordings and measurements of the body weight and shape (Figure 3). They were used in experimental settings to compare health conditions before and after an intervention or to compare groups in different environments. Many of these measures are obtrusive to the participants, sensitive to privacy issues and require medical equipment and expertise, which explains their limited use in field studies. Objective measures for design improvement included, for example, sound and light levels. Objective measures for behavior change were mostly applied by automatic observation using wearables, such as activity trackers and sleep timers, sensors (for example, in chairs or under handrails) and cameras.

\section{Discussion}

\section{Future research}

This study has identified four workplace design strategies based on a sample of peerreviewed papers on interior office space and health. Because of its wide scope and large time span, it is likely that this sample covers most of the approaches in workplace health research and an update would not lead to the identification of different strategies. However, additional strategies and design solutions may emerge from research using different search strings and search engines, including grey literature (books, dissertations) and studying publications on virtual work environments and design of communication technology, phenomena that have increased rapidly during the COVID-19 pandemic.

More design strategies for healthy workplaces may also be identified by analysis of wellbeing theories in the work context. For example, Forooraghi (2020) and Roskams and Haynes (2019) applied the sense of coherence theory onto office environments and argued that a comprehensible, manageable and meaningful workplace will ease health. This implies that next to interventions to support the restoration, enhance social well-being and stimulate physical activity, workplace design strategies could also aim for creating a sense of control, ownership and empowerment or providing clear rules about the use of workspaces. Strategies for empowerment match the positive health definition of Huber et al. (2011), which includes self-management and adaptation. Similarly, the combination of Personenvironment fit and Self-determination theory may suggest a strategy of adjustable design, as needs-supply fit depends on individual, group and job characteristics (AppelMeulenbroek et al., 2020).

Additionally, analysis of design projects that were carried out in practice to improve workers' health may reveal new design strategies by studying their approach, applied design solutions and achieved improvements. We recommend studying projects across different work environments because the effectiveness of design solutions may differ strongly across work environments and work processes. Furthermore, studying the interior design of other environments, for example, health care (healing environment), educational settings (learning environment) and retail (consumer behavior) might reveal design solutions that could be applied to offices. Because design is not deterministic and design changes alone often will not be able to improve health, analyzing practices could also reveal important contextual factors. 
JCRE 24,3

Within the strategies, more evidence-based design solutions could be generated by a larger amount and variety of systematic research on healthy workplaces. Conducting field experiments would generate more knowledge of the designs' effectiveness in real-life settings whereas studies that rely on lab experiments provide a limited simulation of office settings. Longitudinal studies are required to generate insights into the long-term effects of changes in the work environment. For example, the effectiveness of nudges could be tested in field experiments taking measures before implementation and several times during the intervention to track how long its effect lasts in real life. Measuring after the intervention has ended and the stimulus has been taken away will show if the nudging has been able to establish healthy habits. Qualitative research can contribute to the understanding of why applied design solutions do or do not have the desired effect, for example, by conducting spatial walkthroughs, card sorting or experience mapping (Chafi and Cobaleda-Cordero, 2021).

Measurement of well-being in offices could also be improved by further operationalization of well-being concepts and developing measurement scales appropriate to the work context and office environment. General mental health measures may not cover all issues that are relevant to office workers' well-being. For example, social well-being may be context-sensitive and not yet been operationalized accordingly (Colenberg et al., 2020). However, there may be appropriate well-being scales available in psychology that just did not find their way to workplace research.

In addition to contextualized and validated well-being measures, a more fine-grained taxonomy and measurement of actual workplace design features are required to improve measures of effectiveness. The work of, for example, Cobaleda Cordero et al. (2019) on identifying spatial attributes of the office landscape and the work of Kwon et al. (2019), Laurence et al. (2013), Sailer and Thomas (2020), Yildırım et al. (2019) and Zerella et al. (2017) on classifying office furniture, layout characteristics and degrees of enclosure could serve as a basis for further development of design measures.

\section{Practical implications}

The current study offers workplace designers (interior architects and product designers), workplace managers (corporate real estate, facilities and human resources) and their consultants a source of design approaches. The identified strategies and explanation of their mutual relationships could support a wider perspective to healthy workplaces that reach beyond comfort, merging pathogenic and salutogenic approaches to achieve a complete state of health (Keyes, 2014).

This study also shows promising directions for further development of design strategies for healthy workplaces. Obviously, the youngest strategy, nudging healthy behavior, could be explored to a much greater extent. First of all, the targeted behavior could be extended from decreasing sitting time or increasing stair use to, for instance, stimulating a healthy diet, following hygiene measures, taking regular breaks, having walking meetings, cycling to work and any other activity that fits a healthy lifestyle, reduces health risk and generates positive experiences. For instance, nudging could also be applied to engage people in social interactions that enhance their social well-being. Furthermore, additional types of nudges could be developed. In the analyzed studies, most nudges were limited to graphs and warnings while they can take many other forms too. Translating Sunstein's (2014) top 10 nudges into workplace design, one could think of simplifying the use of tools or furniture, access to healthy options (staircase, healthy food) by default and to less-healthy options (elevator, snacks) by request or rewarding desired behavior in several ways, making healthy options more visible, easy and fun. 
Also, the least developed strategy that was identified, called workplace design for social well-being, has potential. Deliberately creating social affordances (Spreitzer et al., 2020), such as coffee bars and opportunities for playful interaction and using technologies to enhance face-to-face interactions at work (Olsson et al., 2020) can increase the frequency or quality of positive interactions and thereby support relationship building. Offering opportunities for privacy regulation is important to facilitate private conversations and to prevent undesired interactions. Identity affordances (Spreitzer et al., 2020), such as incorporating possibilities for personalization and workplace branding into the workplace design, can further increase feelings of belonging and place attachment.

To create restorative environments at work many more aspects of the biophilic design could be applied. The reviewed papers mainly focused on the direct experience of nature in the office through natural light and indoor and outdoor nature views, while (Kellert, 2008) distinguishes six main biophilic design elements and over 70 design attributes. He argues that apart from multi-sensory environmental features, such as plants, color, water and natural materials, the biophilic design could include the use of natural shapes, forms, patterns, processes, light and spatial attributes, as well as the support of place-based and human-nature relationships.

Regarding design for comfort, more design solutions could be developed and tested that reduce environmental stressors and solutions that go beyond ergonomics and instrumental control by further increasing psychological comfort. Vischer (2008) states that psychological comfort results from feelings of belonging, ownership and control over a workspace. Additional means to reduce environmental stress could aim for privacy regulation, for example, items that communicate someone does not want to be disturbed or flexible partitions that could be controlled by the employee. Or they could aim for decreasing fear of contamination by, for example, applying easy-to-clean materials, communicating cleanliness and nudging office users to take protection measures and follow hygiene rules.

\section{Conclusions}

In summary, four interior design strategies that aim to support or increase comfort, restoration, social well-being and healthy behavior, were identified based on a broad literature sample. These strategies invite workplace designers, managers and researchers to take a transdisciplinary view of healthy workplaces and look beyond physical well-being. Although the COVID-19 pandemic initially has forced the attention to hygiene and physical distance, in the longer term the lockdowns and social restrictions made us aware of the human need to connect with each other in person and to get inspired by the environment. Salutogenic design could support people's resilience by replenishing resources for coping with demands. The presented examples of evidence-based design solutions and effectiveness measures could aid in making design decisions explicit and testing assumptions. For academics, this study provides directions for future transdisciplinary workplace research by outlining workplace design features and possibly related well-being aspects, indicating which ones are underexposed and proposing additional research topics and methods.

\section{References}

Aarts, H. and Dijksterhuis, A. (2000), "Habits as knowledge structures: automaticity in goal-directed behavior", Journal of Personality and Social Psychology, Vol. 78 No. 1, pp. 53-63.

Altman, I. (1975), The Environment and Social Behavior: Privacy, Personal Space, Territory, and Crowding, Brooks/Cole Publishing Company, Monterey, CA.

\section{Interior design strategies}

\section{.}


JCRE 24,3

Amick, B.C., Menéndez, C.C., Bazzani, L., Robertson, M., DeRango, K., Rooney, T. and Moore, A. (2012), "A field intervention examining the impact of an office ergonomics training and a highly adjustable chair on visual symptoms in a public sector organization", Applied Ergonomics, Vol. 43 No. 3, pp. 625-631.

Antonovsky, A. (1996), "The salutogenic model as a theory to guide health promotion", Health Promotion International, Vol. 11 No. 1, pp. 11-18.

Appel-Meulenbroek, R., Le Blanc, P. and De Kort, Y.A.W. (2020), "Person-environment fit: optimizing the physical work environment", in Ayoko, O.B. and Ashkanasy, N.M. (Eds), Organizational Behavior and the Psysical Environment, Routledge, New York, NY, pp. 251-267.

Åvitsland, A., Solbraa, A.K. and Riiser, A. (2017), "Promoting workplace stair climbing: sometimes, not interfering is the best", Archives of Public Health, Vol. 75 No. 1, doi: 10.1186/s13690-016-0170-8.

Ayoko, O.B. and Ashkanasy, N.M. (2020), "Conclusions and recommendations for managing the physical environment of work", in Ayoko, O.B. and Ashkanasy, N.M. (Eds), Organizational Behavior and the Physical Environment, Routledge, New York, NY, pp. 306-324.

Barbieri, D.F., Srinivasan, D., Mathiassen, S.E. and Oliveira, A.B. (2017), "Comparison of sedentary behaviors in office workers using sit-stand tables with and without semiautomated position changes", Human Factors: The Journal of the Human Factors and Ergonomics Society, Vol. 59 No. 5, pp. 782-795.

Bjørnstad, S., Patil, G.G. and Raanaas, R.K. (2016), "Nature contact and organizational support during office working hours: benefits relating to stress reduction, subjective health complaints, and sick leave", Work, Vol. 53 No. 1, pp. 9-20.

Bluyssen, P.M., Aries, M. and Van Dommelen, P. (2011), "Comfort of workers in office buildings: the european HOPE project”, Building and Environment, Vol. 46 No. 1, pp. 280-288.

Bodin Danielsson, C., Bodin, L., Wulff, C. and Theorell, T. (2015), "The relation between office type and workplace conflict: a gender and noise perspective", Journal of Environmental Psychology, Vol. 42, pp. 161-171.

Bodin Danielsson, C., Chungkham, H.S., Wulff, C. and Westerlund, H. (2014), “Office design's impact on sick leave rates", Ergonomics, Vol. 57 No. 2, pp. 139-147.

Boerstra, A.C., Te Kulve, M., Toftum, J., Loomans, M.G.L.C., Olesen, B.W. and Hensen, J.L.M. (2015), "Comfort and performance impact of personal control over thermal environment in summer: results from a laboratory study", Building and Environment, Vol. 87, pp. 315-326.

Boubekri, M., Cheung, I.N., Reid, K.J., Wang, C.H. and Zee, P.C. (2014), "Impact of windows and daylight exposure on overall health and sleep quality of office workers: a case-control pilot study", Journal of Clinical Sleep Medicine, Vol. 10 No. 6, pp. 603-611.

Brennan, A., Chugh, J.S. and Kline, T. (2002), “Traditional versus open office design”, Environment and Behavior, Vol. 34 No. 3, pp. 279-299.

Brown, G., Lawrence, T.B. and Robinsohn, S.L. (2005), “Territoritality in organisations”, Academy of Management Review, Vol. 30 No. 3, pp. 577-594.

Carr, L.J., Swift, M., Ferrer, A. and Benzo, R. (2016), “Cross-sectional examination of long-term access to sit-stand desks in a professional office setting", American Journal of Preventive Medicine, Vol. 50 No. 1, pp. $96-100$.

Chafi, M.B. and Cobaleda-Cordero, A. (2021), "Methods for eliciting user experience insights in workplace studies: spatial walkthroughs, experience curve mapping and card sorting", Journal of Corporate Real Estate, doi: 10.1108/JCRE-12-2020-0069.

Chan, J.K., Beckman, S.L. and Lawrence, P.G. (2007), “California management review workplace design: a new managerial imperative”, California Management Review, Vol. 49 No. 2, pp. 6-22.

Ching, F.D.K. and Binggeli, C. (2018), Interior Design Illustrated, 4th ed., John Wiley and Sons Inc., Hoboken, NJ. 
Cirrincione, L., Plescia, F., Ledda, C., Rapisarda, V., Martorana, D., Moldovan, R.E., Theodoridou, K., et al. (2020), "COVID-19 pandemic: prevention and protection measures to be adopted at the workplace”, Sustainability, Vol. 12 No. 9, doi: 10.3390/su12093603.

Cobaleda Cordero, A., Babapour, M. and Karlsson, M. (2019), "Feel well and do well at work", Journal of Corporate Real Estate, Vol. 22 No. 2, pp. 113-137.

Cohen, S., Kamarck, T. and Mermelstein, R. (1983), “A global measure of perceived stress”, Journal of Health and Social Behavior, Vol. 24 No. 4, pp. 385-396.

Colenberg, S., Jylhä, T. and Arkesteijn, M. (2021), "The relationship between interior office space and employee health and well-being - a literature review", Building Research and Information, Vol. 49 No. 3, pp. 352-366.

Colenberg, S., Appel-Meulenbroek, R., Romero Herrera, N. and Keyson, D. (2020), "Conceptualization of social well-being in activity-based offices", Journal of Managerial Psychology, Vol. 36 No. 4, pp. 327-343.

De Kort, Y. and Smolders, K. (2010), "Effects of dynamic lighting on office workers: first results of a field study with monthly alternating settings", Lighting Research and Technology, Vol. 42 No. 3, pp. 345-360.

Demerouti, E., Bakker, A.B., Nachreiner, F. and Schaufeli, W.B. (2001), "The job demands-resources model of burnout", Journal of Applied Psychology, Vol. 86 No. 3, pp. 499-512.

Desmet, P.M.A. and Pohlmeyer, A.E. (2013), "Positive design: an introduction to design for subjective well-being", International Journal of Design, Vol. 7 No. 3, pp. 5-19.

Duncan, M.J., Short, C., Rashid, M., Cutumisu, N., Vandelanotte, C. and Plotnikoff, R.C. (2015), "Identifying correlates of breaks in occupational sitting: a cross-sectional study", Building Research and Information, Vol. 43 No. 5, pp. 646-658.

Engelen, L., Chau, J., Bohn-Goldbaum, E., Young, S., Hespe, D. and Bauman, A. (2017), "Is active design changing the workplace? A natural pre-post experiment looking at health behavior and workplace perceptions", Work, Vol. 56 No. 2, pp. 229-237.

Engelen, L., Chau, J., Young, S., Mackey, M., Jeyapalan, D. and Bauman, A. (2019), "Is activity-based working impacting health, work performance and perceptions? A systematic review", Building Research and Information, Vol. 47 No. 4, pp. 468-479.

Engelen, L., Dhillon, H.M., Chau, J.Y., Hespe, D. and Bauman, A.E. (2016), "Do active design buildings change health behavior and workplace perceptions?", Occupational Medicine, Vol. 66 No. 5 , pp. 408-411.

Evensen, K.H., Raanaas, R.K., Hagerhall, C.M., Johansson, M. and Patil, G.G. (2015), "Restorative elements at the computer workstation", Environment and Behavior, Vol. 47 No. 3, pp. 288-303.

Fisher, C.D. (2014), "Conceptualizing and measuring wellbeing at work", in Chen, P.Y. and Cooper, C.L. (Eds), Wellbeing: A Complete Reference Guide, Work and Wellbeing, Wiley Blackwell, New York, NY, pp. 9-34.

Fjeld, T. (2000), "The effect of interior planting on health and discomfort among workers and school children", HortTechnology, Vol. 10 No. 1, pp. 46-52.

Foley, B., Engelen, L., Gale, J., Bauman, A. and Mackey, M. (2016), "Sedentary behavior and musculoskeletal discomfort are reduced when office workers trial an activity-based work environment", Journal of Occupational and Environmental Medicine, Vol. 58 No. 9, pp. 924-931.

Forooraghi, M., Miedema, E., Ryd, N. and Wallbaum, H. (2020), "Scoping review of health in office design approaches", Journal of Corporate Real Estate, Vol. 22 No. 2, pp. 155-180.

Forooraghi, M. (2020), "Health and office architecture: exploring the salutogenic approach in the context of the physical office environment", Doctoral dissertation, Chalmers University of Technology, available at: https://research.chalmers.se/publication/517174/file/517174_Fulltext.pdf

Fostervold, K. and Nersveen, J. (2008), "Proportions of direct and indirect indoor lighting - the effect on health, well-being and cognitive performance of office workers", Lighting Research and Technology, Vol. 40 No. 3, pp. 175-200. 
JCRE 24,3

Graves, L.E.F., Murphy, R.C., Shepherd, S.O., Cabot, J. and Hopkins, N.D. (2015), "Evaluation of sit-stand workstations in an office setting: a randomised controlled trial”, BMC Public Health, Vol. 15 No. 1, p. 1145.

Grooten, W.J.A., Äng, B.O., Hagströmer, M., Conradsson, D., Nero, H. and Franzén, E. (2017), "Does a dynamic chair increase office workers' movements? Results from a combined laboratory and field study", Applied Ergonomics, Vol. 60, pp. 1-11.

Haapakangas, A., Hongisto, V., Varjo, J. and Lahtinen, M. (2018), "Benefits of quiet workspaces in open-plan offices - evidence from two office relocations", Journal of Environmental Psychology, Vol. 56, pp. 63-75.

Hanc, M., McAndrew, C. and Ucci, M. (2019), "Conceptual approaches to wellbeing in buildings: a scoping review”, Building Research and Information, Vol. 47 No. 6, pp. 767-783.

Hartig, T., Korpela, K., Evans, G.W. and Gärling, T. (1997), "A measure of restorative quality in environments", Scandinavian Housing and Planning Research, Vol. 14 No. 4, pp. 175-194.

Healy, G.N., Eakin, E.G., LaMontagne, A.D., Owen, N., Winkler, E.A.H., Wiesner, G., Gunning, L., et al. (2013), "Reducing sitting time in office workers: short-term efficacy of a multicomponent intervention", Preventive Medicine, Vol. 57 No. 1, pp. 43-48.

Huber, M. André Knottnerus, J., Green, L., Van Der Horst, H., Jadad, A.R., Kromhout, D., Leonard, B., et al. (2011), "How should we define health?", BMJ, Vol. 343 No. 2, pp. 1-3.

Jaakkola, J.J.K. and Heinonen, O.P. (1995), "Shared office space and the risk of the common cold", European Journal of Epidemiology, Vol. 11 No. 2, pp. 213-216.

Jahncke, H., Hygge, S., Halin, N., Green, A.M. and Dimberg, K. (2011), “Open-plan office noise: cognitive performance and restoration”, Journal of Environmental Psychology, Vol. 31 No. 4, pp. 373-382.

Jancey, J.M., McGann, S., Creagh, R., Blackford, K.D., Howat, P. and Tye, M. (2016), "Workplace building design and office-based workers' activity: a study of a natural experiment", Australian and New Zealand Journal of Public Health, Vol. 40 No. 1, pp. 78-82.

Jensen, P.A. and van der Voordt, T.J.M. (2020), "Healthy workplaces: what we know and what else we need to know", Journal of Corporate Real Estate, Vol. 22 No. 2, pp. 95-112.

Joines, S., James, T., Liu, S., Wang, W., Dunn, R. and Cohen, S. (2015), "Adjustable task lighting: field study assesses the benefits in an office environment”, Work, Vol. 51 No. 3, pp. 471-481.

Kahn, P.H., Friedman, B., Gill, B., Hagman, J., Severson, R.L., Freier, N.G., Feldman, E.N., et al. (2008), "A plasma display window? The shifting baseline problem in a technologically mediated natural world”, Journal of Environmental Psychology, Vol. 28 No. 2, pp. 192-199.

Kaplan, S. (1995), "The restorative benefits of nature: toward an integrative framework", Journal of Environmental Psychology, Vol. 15 No. 3, pp. 169-182.

Karakolis, T. and Callaghan, J.P. (2014)“The impact of sit-stand office workstations on worker discomfort and productivity: a review", Applied Ergonomics, Vol. 45 No. 3, pp. 799-806.

Kellert, S.R. (2008), "Dimensions, elements, and attributes of biophilic design", in Kellert, S.R., Heerwagen, J.H. and Mador, M.L. (Eds), Biophilic Design: The Theory, Science, and Practice of Bringing Buildings to Life, 1st ed., John Wiley and Sons, Hoboken, NJ, pp. 3-19.

Keyes, C.L.M. (2014), "Mental health as a complete state: how the salutogenic perspective completes the picture", in Bauer, G.F. and Hämmig, O. (Eds), Bridging Occupational, Organizational and Public Health, Springer, Dordrecht, pp. 179-192.

Knight, C. and Haslam, S.A. (2010), "Your place or mine? Organizational identification and comfort as mediators of relationships between the managerial control of workspace and employees' satisfaction and well-being", British Journal of Management, Vol. 21 No. 3, pp. 717-735.

Kwak, L., Kremers, S.P.J., Van Baak, M.A. and Brug, J. (2007), “A poster-based intervention to promote stair use in blue- and white-collar worksites”, Preventive Medicine, Vol. 45 Nos 2/3, pp. 177-181.

Kweon, B.S., Ulrich, R.S., Walker, V.D. and Tassinary, L.G. (2008), "Anger and stress: the role of landscape posters in an office setting”, Environment and Behavior, Vol. 40 No. 3, pp. 355-381. 
Kwon, M., Remøy, H. and van den Bogaard, M. (2019), "Influential design factors on occupant satisfaction with indoor environment in workplaces", Building and Environment, Vol. 157, pp. 356-365.

Interior design strategies

Lamb, S. and Kwok, K.C.S. (2016), "A longitudinal investigation of work environment stressors on the performance and wellbeing of office workers", Applied Ergonomics, Vol. 52, pp. 104-111.

Laurence, G.A., Fried, Y. and Slowik, L.H. (2013), "My space': a moderated mediation model of the effect of architectural and experienced privacy and workspace personalization on emotional exhaustion at work", Journal of Environmental Psychology, Vol. 36, pp. 144-152.

Lewis, A. and Eves, F. (2012), "Prompt before the choice is made: effects of a stair-climbing intervention in university buildings", British Journal of Health Psychology, Vol. 17 No. 3, pp. 631-643.

Lindberg, C.M., Srinivasan, K., Gilligan, B., Razjouyan, J., Lee, H., Najafi, B., Canada, K.J., et al. (2018), "Effects of office workstation type on physical activity and stress", Occupational and Environmental Medicine, Vol. 75 No. 10, pp. 689-695.

Meijer, E.M., Frings-Dresen, M.H.W. and Sluiter, J.K. (2009), "Effects of office innovation on office workers' health and performance", Ergonomics, Vol. 52 No. 9, pp. 1027-1038.

Miles, M.B., Huberman, M.A. and Saldaña, J. (2020), Qualitative Data Analysis: A Method Sourcebook, SAGE Publications Inc., Thousand Oaks, CA.

Morrison, R.L. and Macky, K.A. (2017), "The demands and resources arising from shared office spaces", Applied Ergonomics, Vol. 60, pp. 103-115.

Nicoll, G. and Zimring, C. (2009), "Effect of innovative building design on physical activity", Journal of Public Health Policy, Vol. 30 No. 1, pp. S111-S123.

Nocon, M., Müller-Riemenschneider, F., Nitzschke, K. and Willich, S.N. (2010), "Increasing physical activity with point-of-choice prompts - a systematic review", Scandinavian Journal of Public Health, Vol. 38 No. 6, pp. 633-638.

Olsson, T., Jarusriboonchai, P., Woźniak, P., Paasovaara, S., Väänänen, K. and Lucero, A. (2020), "Technologies for enhancing collocated social interaction: review of design solutions and approaches", Computer Supported Cooperative Work (Cscw), Vol. 29 Nos 1/2, pp. 29-83.

Pejtersen, J., Allermann, L., Kristensen, T.S.T.S. and Poulsen, O.M.M. (2006), "Indoor climate, psychosocial work environment and symptoms in open-plan offices", Indoor Air, Vol. 16 No. 5, pp. 392-401.

Pejtersen, J.H., Feveile, H., Christensen, K.B. and Burr, H. (2011), "Sickness absence associated with shared and open-plan offices - a national cross sectional questionnaire survey", Scandinavian Journal of Work, Environment and Health, Vol. 37 No. 5, pp. 376-382.

Qin, J., Sun, C., Zhou, X., Leng, H. and Lian, Z. (2014), "The effect of indoor plants on human comfort", Indoor and Built Environment, Vol. 23 No. 5, pp. 709-723.

Robertson, M.M., Ciriello, V.M. and Garabet, A.M. (2013), "Office ergonomics training and a sit-stand workstation: effects on musculoskeletal and visual symptoms and performance of office workers", Applied Ergonomics, Vol. 44 No. 1, pp. 73-85.

Robertson, M., Amick, B.C., DeRango, K., Rooney, T., Bazzani, L., Harrist, R. and Moore, A. (2009), "The effects of an office ergonomics training and chair intervention on worker knowledge, behavior and musculoskeletal risk", Applied Ergonomics, Vol. 40 No. 1, pp. 124-135.

Roossien, C.C., Stegenga, J., Hodselmans, A.P., Spook, S.M., Koolhaas, W., Brouwer, S., Verkerke, G.J., et al. (2017), "Can a smart chair improve the sitting behavior of office workers?", Applied Ergonomics, Vol. 65, pp. 355-361.

Roskams, M. and Haynes, B. (2019), "Salutogenic workplace design: a conceptual framework for supporting sense of coherence through environmental resources", Journal of Corporate Real Estate, Vol. 22 No. 2, pp. 139-153.

Sailer, K. and Thomas, M. (2020), "Socio-spatial perspectives on open-plan versus cellular offices", Journal of Managerial Psychology, Vol. 36 No. 4, pp. 382-399. 
JCRE 24,3

Schlittmeier, S.J. and Liebl, A. (2015), "The effects of intelligible irrelevant background speech in offices - cognitive disturbance, annoyance, and solutions", Facilities, Vol. 33 Nos 1/2, pp. 61-75.

Seddigh, A., Berntson, E., Jönsson, F., Danielson, C.B. and Westerlund, H. (2015), "The effect of noise absorption variation in open-plan offices: a field study with a cross-over design", Journal of Environmental Psychology, Vol. 44, pp. 34-44.

Shafiee Motlagh, M., Golmohammadi, R., Aliabadi, M., Faradmal, J. and Ranjbar, A. (2018), "Empirical study of room acoustic conditions and neurophysiologic strain in staff working in special openplan bank offices”, Acoustics Australia, Vol. 46 No. 3, pp. 329-338.

Snyder, H. (2019), "Literature review as a research methodology: an overview and guidelines", Journal of Business Research, Vol. 104, pp. 333-339.

Sommer, R. (1974), Tight Spaces; Hard Architecture and How to Humanize It, Prentice Hall, Hoboken, NJ.

Spreitzer, G., Bacevice, P. and Garrett, L. (2020), "Workplace design, the physical environment, and human thriving at work", in Ayoko, O.B. and Ashkanasy, N.M. (Eds), Organizational Behavior and the Psysical Environment, Routledge, New York, NY, pp. 235-250.

Sunstein, C.R. (2014), "Nudging: a very short guide", Journal of Consumer Policy, Vol. 37 No. 4, pp. 583-588.

Swenson, T. and Siegel, M. (2013), "Increasing stair use in an office worksite through an interactive environmental intervention”, American Journal of Health Promotion, Vol. 27 No. 5, pp. 323-329.

Thaler, R.H. and Sunstein, C.R. (2008), Nudge: Improving Decisions about Health, Wealth, and Happiness, Yale University Press, New Haven, CT, doi: 10.1007/s10602-008-9056-2.

Thayer, J.F., Verkuil, B., Brosschotj, J.F., Kevin, K., West, A., Sterling, C., Christie, I.C., et al. (2010), "Effects of the physical work environment on physiological measures of stress", European Journal of Cardiovascular Prevention and Rehabilitation, Vol. 17 No. 4, pp. 431-439.

Toftum, J. (2010), "Central automatic control or distributed occupant control for better indoor environment quality in the future", Building and Environment, Vol. 45 No. 1, pp. 23-28.

Torbeyns, T., de Geus, B., Bailey, S., De Pauw, K., Decroix, L., Van Cutsem, J. and Meeusen, R. (2016), "Bike desks in the office", Journal of Occupational and Environmental Medicine, Vol. 58 No. 12, pp. 1257-1263.

U.S. Bureau of Labor Statistics (2020), "Employment by major occupational group”, available at: www. bls.gov/emp/tables/emp-by-major-occupational-group.htm (accessed 15 December 2020).

Ulrich, R.S., Simons, R.F., Losito, B.D., Fiorito, E., Miles, M.A. and Zelson, M. (1991), "Stress recovery during exposure to natural and urban environments", Journal of Environmental Psychology, Vol. 11 No. 3, pp. 201-230.

Van de Voorde, K., Paauwe, J. and Van Veldhoven, M. (2012), "Employee well-being and the HRMorganizational performance relationship: a review of quantitative studies”, International Journal of Management Reviews, Vol. 14 No. 4, pp. 391-407.

Van Duijnhoven, J., Aarts, M.P.J., Rosemann, A.L.P. and De Kort, H.S.M. (2018), “Ambiguities regarding the relationship between office lighting and subjective alertness: an exploratory field study in a dutch office landscape", Building and Environment, Vol. 142, pp. 130-138.

Van Niekerk, S.M., Louw, Q.A. and Hillier, S. (2012), "The effectiveness of a chair intervention in the workplace to reduce musculoskeletal symptoms. A systematic review”, BMC Musculoskeletal Disorders, Vol. 13 No. 1, p. 145.

Veitch, J.A.J., Newsham, G.R.G., Boyce, P.R. and Jones, C.C. (2008), "Lighting appraisal, well-being and performance in open-plan offices: a linked mechanisms approach”, Lighting Research and Technology, Vol. 40 No. 2, pp. 133-151.

Venema, T. and van Gestel, L. (2021), "Nudging in the workplace: facilitating desirable behavior by changing the environment”, in Appel-Meulenbroek, R. and Danivska, V. (Eds), A Handbook of 
Theories on Designing Alignment between People and the Office Environment, 1st ed., Routledge, London, pp. 222-235.

Viola, A.U., James, L.M., Schlangen, L.J. and Dijk, D.J. (2008), "Blue-enriched white light in the workplace improves self-reported alertness, performance and sleep quality”, Scandinavian Journal of Work, Environment and Health, Vol. 34 No. 4, pp. 297-306.

Vischer, J.C. (2008), "Towards a user-centred theory of the built environment”, Building Research and Information, Vol. 36 No. 3, pp. 231-240.

Wells, M.M. (2000), "Office clutter or meaningful personal displays: the role of office personalization in employee and organizational well-being", Journal of Environmental Psychology, Vol. 20 No. 3, pp. 239-255.

WHO (2006), "Constitution of the world health organization", available at: www.who.int/governance/ eb/who_constitution_en.pdf

Wilkerson, A.H., Usdan, S.L., Knowlden, A.P., Leeper, J.L., Birch, D.A. and Hibberd, E.E. (2018), "Ecological influences on employees' workplace sedentary behavior: a cross-sectional study", American Journal of Health Promotion, Vol. 32 No. 8, pp. 1688-1696.

Wilson, E.O. (1984), Biophilia, Harvard University Press, London.

World Green Building Council (2014), "Health, wellbeing and productivity in offices: the next chapter for green building", available at: www.worldgbc.org/news-media/health-wellbeing-andproductivity-offices-next-chapter-green-building

Xue, F., Gou, Z. and Lau, S. (2016), "Human factors in green office building design: the impact of workplace green features on health perceptions in high-rise high-density Asian cities", Sustainability, Vol. 8 No. 11, p. 1095.

Y1ldırım, K., Günes, E. and Pervan Yilmaz, G. (2019), "The effects of workstation partition heights on employees' perceptions in open-plan offices", Journal of Corporate Real Estate, Vol. 21 No. 2, pp. 165-183.

Zerella, S., von Treuer, K. and Albrecht, S.L. (2017), “The influence of office layout features on employee perception of organizational culture", Journal of Environmental Psychology, Vol. 54, pp. 1-10.

\begin{abstract}
About the authors
Susanne Colenberg has a degree in both organizational psychology (Leiden University) and interior architecture (Royal Academy of Arts, The Hague). After working for over 20 years as a researcher and workplace consultant, she currently is a $\mathrm{PhD}$ candidate at the Department of Human-Centered Design, Faculty of Industrial Design Engineering, Delft University of Technology. In her PhD research, she studies how workplace design could support social well-being in offices. Susanne Colenberg is the corresponding author and can be contacted at: s.e.colenberg@tudelft.nl

Tuuli Jylhä is an assistant professor of Real Estate Management at the Department of Management in the Built Environment, Faculty of Architecture and the Built Environment, Delft University of Technology. In her research, she is interested in long-term circularity in real estate management (REM). She integrates waste prevention and value delivery theories from lean management into (corporate) real estate management theories to improve resource efficiency and effectiveness. Her passion is to move the REM industry toward near-zero waste.
\end{abstract}

For instructions on how to order reprints of this article, please visit our website:

www.emeraldgrouppublishing.com/licensing/reprints.htm

Or contact us for further details: permissions@emeraldinsight.com 